\title{
Linguagem e negação: sobre as relações entre pragmática e ontologia em Hegel
}

\author{
Vladimir Safatle \\ Universidade de São Paulo
}

resumo Trata-se de abordar o problema da teoria hegeliana da linguagem a partir do ponto onde pragmática e ontologia se articulam. Isto exige uma reflexão sobre a maneira com que Hegel organiza as dinâmicas da pragmática da linguagem levando em conta os modos de manifestação de uma negação ontológica no interior do campo de experiências lingüísticas da consciência.

palavras-chave dialética, negação, linguagem, pragmática, atos de fala, contradição

Ao Ruy,

Se a filosofia pudesse ser definida, ela seria um esforço

de expressar aquilo do qual não se pode falar,

expressar o não-idêntico a despeito do fato de que expressá-lo

identifica-o.

Hegel procurou isto.

Adorno

\section{Uma certa guinada lingüística}

É provável que a indagação sobre o sentido da dialética no interior da experiência intelectual hegeliana deva levar em conta a maneira como teoria da linguagem e ontologia se entrelaçam nos textos do filósofo alemão. Sabemos como Hegel procura livrar a filosofia de seu tempo deste "espetáculo estranho de um povo formado (gebildetes) desprovido de metafísica - como é o caso de um templo dotado de ornamentos variados, mas privado de santuário" (HEGEL, 1986, p. 14). No entanto, o

Recebido em 15 de dezembro de 2005. Aceito em 12 de março de 2006.

doispontos, Curitiba, São Carlos, vol. 3, n. 1, p.109-146, abril, 2006 
recurso a uma reflexão ontológica renovada parece, várias vezes, dependente de decisões anteriores sobre o modo de funcionamento da linguagem em suas expectativas referenciais e no interior de práticas de interação social.

Esta articulação entre teoria da linguagem e ontologia não implica, necessariamente, uma espécie de subsunção através da qual considerações ontológicas determinariam, de maneira normativa, a racionalidade de experiências lingüísticas. $\mathrm{Na}$ verdade, trata-se de mostrar como, em Hegel, a exploração de problemas lingüísticos (como, por exemplo, o descompasso entre exigências de sentido e determinação da referência, ou ainda, entre significação e designação, descompasso presente tanto nos processos de nomeação quanto nos atos de fala de auto-referência) exige que eles sejam resolvidos através de uma recuperação do campo da ontologia. De fato, isto implica não apenas afirmar que, para Hegel, problemas lingüísticos têm necessariamente uma dignidade ontológica, já que isto pode ser compreendido simplesmente como uma afirmação que esvaziaria o campo da ontologia por ver ali nada mais do que problemas lingüísticos. Correndo o risco de pecar por anacronismo, podemos dizer que a articulação hegeliana entre teoria da linguagem e ontologia visa, na verdade, invalidar afirmações como: "O que torna as questões ontológicas sem significado quando tomadas em sentido absoluto não é a universalidade, mas a circularidade. Uma questão da forma $O$ que é um F? somente pode ser respondida por recurso a um outro termo: Um F é um G. A resposta tem somente um sentido relativo: um sentido relativo à aceitação não crítica de G" (QUINE, 1980, pp. 147-148).

No entanto, parece-nos que o recurso hegeliano à ontologia não resulta nesta segurança da posição do ser em uma positividade, tal como ela é pressuposta pela afirmação de Quine (como se a ontologia fosse o resultado de uma certa naturalização da "aceitação não-crítica de G"). Ao contrário, a estratégia hegeliana só poderá ser devidamente compreendida à luz da centralidade de sua desvinculação entre ontologia e positividade, ou seja, de sua recuperação do que alguns comentadores chamaram de "dignidade ontológica da negação". Trata-se de um dos temas maiores de trabalhos como os de Gérard Lebrun sobre Hegel: o cerne da ontologia hegeliana está assentado em um "re-exame ontológico das categorias do positivo e do negativo" (LEBRUN, 1971, 
p. 290) que o teria levado a reconstruir o campo da ontologia ao questionar a noção clássica de que a negação não tem nenhuma realidade em si. Compartilhar tal perspectiva nos permite dizer que a dialética hegeliana é solidária de uma teoria da linguagem cujo fundamento se encontra em um conceito ontológico de negação como modo de manifestação do que é essencialmente determinado.

Por fim, trata-se ainda de mostrar que tal articulação entre teoria da linguagem e ontologia não invalida necessariamente leituras contemporâneas de Hegel, como as de Robert Brandom, para quem é possível identificar a existência de certos temas maiores próprios ao pragmatismo em operação no interior do idealismo hegeliano. Temas como, por exemplo, a noção de que o uso dos conceitos determina seu conteúdo semântico.

Veremos adiante como Hegel fornece vários exemplos neste sentido. Ou seja, ele está claramente disposto a mostrar como o conteúdo semântico do conceito é determinado pela experiência feita pela consciência. Experiência que não é outra coisa senão práxis que visa a conceitualização do que aparece. No entanto, esta experiência só será tematizada de maneira adequada quando compreendermos como ela se realiza naturalmente na determinação de categorias ontológicas. A dimensão ontológica da negação deve orientar a experiência da consciência, quer dizer, ela deve se revelar no interior das operações práticas dos sujeitos.

Uma articulação improvável entre pragmática e ontologia parece assim se desenhar no interior da experiência intelectual hegeliana e de seu conceito de dialética.

\section{0 problema do arbitrário do signo ou Por que Hegel não é estruturalista?}

A fim de introduzir algumas considerações iniciais sobre a teoria hegeliana da linguagem, convém partir de uma distinção central operada pelo filósofo alemão entre símbolo, signo e conceito.

Para Hegel, o signo está ligado à lógica da representação e da adequação própria ao que a doutrina da essência chama de reflexão exterior (äusserliche Reflexion). De onde se segue a definição canônica: "O signo 
(Zeichen) é uma certa intuição (Anschauung) imediata que representa (vorstellt) um conteúdo absolutamente distinto daquele que a intuição tem para si; ele é a pirâmide para a qual uma alma estrangeira foi transferida e conservada" (HEGEL, 2000, \458). A relação arbitrária que o signo sustenta é assim evidente, pois ele representa um conteúdo distinto do que aparece à intuição. Estranha 'intuição imediata' esta posta pelo signo, já que é uma intuição que conserva a distância entre o conteúdo intuído e o conteúdo representado, entre o que é visado (Meinung) e o que é efetivamente dito. Distância figurada nesta pirâmide, neste túmulo de pedra que guarda em si uma alma estranha que, no entanto, é fonte de significado. Em um texto célebre, Derrida vira, no motivo da pirâmide, a figuração perfeita de uma noção de signo como junção entre significante material e significado que continuará presente ainda em Saussure. Figuração que nos levaria a compreender o signo como: "uma espécie de intuição da ausência [em relação à presença material da referência] ou, mais precisamente, a visada de uma ausência através de uma intuição plena" (DERRIDA, 1991, p. 120).

Contra o arbitrário do signo (ou contra seu "arbítrio" - Willkür), Hegel contrapõe inicialmente o caráter motivado do símbolo, no qual o conteúdo da intuição é "mais ou menos"apresentado no que o símbolo exprime. Mas não é através das vias do simbolismo que a dialética hegeliana passará.

Retornemos ao Curso de estética a fim de compreender a necessidade hegeliana de ultrapassar a linguagem simbólica. Aqui, descobrimos como a adequação entre significação e imagem sensível nas formas simbólicas é ainda imperfeita, pois, na verdade, a motivação do símbolo é contextual. Ela depende de uma convenção partilhada já que o símbolo é uma metonímia articulada através de relações analógicas entre a significação e um atributo no interior de uma multiplicidade de atributos do que é imediatamente representado pela imagem sensível. A força, por exemplo, é um dos atributos da multiplicidade que compõe o leão.

$\mathrm{Na}$ verdade, o símbolo é o caso mais visível de um problema geral denunciado pela filosofia hegeliana: a impossibilidade de fundar o sentido através da pressuposição da imediatidade de uma referência naturalizada. A experiência imediata não possui a unidade de um domínio autônomo. $\mathrm{O}$ apelo à referência sempre é indeterminado, ela sempre 
desliza através do infinito ruim da multiplicidade de perspectivas possíveis de apreensão. A linguagem alegórica do símbolo esconde sempre uma hermenêutica capaz de fornecer um ponto de basta capaz de parar a fuga infinita do sentido. A imagem sensível do triângulo em uma igreja cristã, por exemplo, pressupõe a existência de um texto escondido que nos permite passar do triângulo à Trindade.

No parágrafo em questão da Enciclopédia, Hegel parece mais interessado na atividade criadora dos signos. Atividade que consiste em negar o imediato da intuição sensível a fim de possibilitar a produção de um "outro conteúdo como significação e alma". É apenas desta maneira que a consciência pode se liberar da ilusão da imanência da particularidade própria à certeza sensível e aceder ao início do saber. Há aqui uma negação da faticidade da referência sensível que, na Fenomenologia do Espírito, é louvada como sendo a própria "energia do pensar, do puro Eu”, isto quando Hegel afirma que: "A atividade do dividir é a força e o trabalho do entendimento, a força maior e mais maravilhosa, ou melhor: a potência absoluta" (HEGEL, 1992a, p. 38; 1988, p. 25). Força maravilhosa cujo nome correto é: abstração em relação ao sensível.

A princípio, esta força de abstração que encontra sua manifestação na arbitrariedade do signo parece a realização necessária de um conceito de Espírito (Geist) que fora anteriormente definido, logo no início da seção da Enciclopédia dedicada à psicologia (seção da qual as reflexões sobre o signo lingüístico fazem parte), como:"o que se elevou (erhoben) por sobre a natureza e a determinidade natural, como por sobre a imbricação (Verwicklung) com um objeto exterior, ou seja, por sobre o que é em geral material (das Materielle überhaupt)" (HEGEL, 2000, \440). O que "há de negativo na atividade do Espírito" pareceria assim encontrar lugar necessariamente na gramática do signo e de seu (e por que não ressuscitar aqui uma temática cara a Alexandre Kojève?) "assassinato da imediatidade sensível da Coisa".

No entanto, a dialética não é um conhecimento por signos. A negatividade do signo em seu poder de abstração não é ainda a manifestação ontológica da negação procurada pela dialética, desta negação que nos dá acesso à determinação da essência de uma Coisa mesma (Sache selbst) reconciliada com a dimensão da empiria. Ao contrário, ela é apenas anulação, negação simples e sem retorno. Por isto, pensar através de signos 
é ainda pensar sobre o fundo da distância, é ainda estar aferrado à representação e a seu exílio em relação ao sensível. O que Hegel procura é, ao contrário, uma gramática filosófica capaz de reconciliar esta cisão, tão própria ao signo, entre sentido e referência. Para Hegel, é claro que o conhecimento por signos afirma mais do que admite. No fundo, o signo esconde uma perspectiva externalista na compreensão da relação entre linguagem e referência. Pois é a partir de uma perspectiva externalista fundada na noção de verdade como adequação que posso afirmar que o signo será sempre arbitrário se comparado à intuição sensível. Precisamos aqui de uma gramática que anule a necessidade de um vocabulário do arbitrário sem que isto signifique entrar nas vias de uma linguagem fundada no caráter motivado e expressivo do símbolo.

O tema hegeliano do arbitrário do signo já anuncia uma discussão que terá a função de pedra de toque no interior da lingüística estrutural do século XX. Sabemos que o significante é:“imotivado, ou seja, arbitrário em relação ao significado, com o qual ele não tem nenhuma ligação natural na realidade" (SAUSSURE, 1972, p. 101) ${ }^{1}$, dirá Saussure. Tanto $b$-ö-f quanto $o-k$-s representam o mesmo conceito (significado), o que demonstra o arbitrário da relação. Mas, na verdade, tal arbitrário também indica um modo de relação entre signo e referência, já que, como nos lembra Benveniste em um texto célebre (BENVENISTE, 1966, pp. 50-51), eles são arbitrários porque se referem à mesma realidade extralingüística. Ou seja, há uma certa teoria naturalizada da referência sustentando o argumento de Saussure. Tudo se passa como se pudéssemos identificar a existência de uma espécie natural (natural kind) a fim de afirmar que ela pode ser representada tanto por $b-\ddot{o}-f$, por $o-k-s$ ou por qualquer som.

A noção de arbitrário pressupõe assim a possibilidade de uma comparação entre os conteúdos de representações mentais e objetos, propriedades e relações existentes em um mundo que seria largamente independente de nosso discurso. Entramos aqui no famoso paradoxo presente na questão profissional posta pelo ceticismo, tal qual ela foi formulada por Richard Rorty: "Como sabemos nós que tudo aquilo que é mental representa algo que não é mental? Como sabemos nós se aquilo que o Olho da Mente vê é um espelho (ainda que distorcido - um vidro encantado) ou um véu?” (RORTY, 1988, p. 46). 
A respeito desta questão sobre o arbitrário do signo, poderíamos seguir uma vertente tipicamente estruturalista e afirmar que: "O arbitrário recobre, de maneira extremamente ajustada, uma questão que não será posta: o que é o signo quando ele não é o signo? O que é a língua antes de ser a língua? - ou seja, a questão que exprimimos corriqueiramente em termos de origem. Dizer que o signo é arbitrário é pôr a tese primitiva: há língua" (MILNER, 1978, p. 59). Tal eliminação de toda questão sobre a origem nos levaria, necessariamente, a adotar a tese "kantiana" segundo a qual: "a ligação que une as coisas enquanto coisas não pode ter nada em comum com a linguagem que as une enquanto faces de um signo: nenhuma causa relevante da primeira pode operar sobre a segunda" (MILNER, 1978, p. 58).

Para a dialética hegeliana, no entanto, esta clivagem entre a língua e o que vem antes da língua, ou seja, a referência em sua autonomia metafisica, é apenas um momento (absolutamente necessário) do movimento próprio à compreensão especulativa da pragmática da linguagem. A hipóstase deste momento significa a conservação de uma perspectiva externalista na compreensão da referência que absolutiza o que não tem vínculo com a determinação essencial da coisa. Para a dialética, não se trata de retornar à questão da origem, mas de inverter a perspectiva e compreender a ligação das coisas como, de uma certa forma, causada pela estruturação de oposições e de diferenças própria à linguagem. Brandom chamou, com propriedade, esta perspectiva filosófica de holismo semântico: ou seja, a idéia de que as relações entre conceitos são condição suficiente (e não apenas condição necessária) para a determinação do conteúdo do que se coloca como objeto da experiência (BRANDOM, 2002) ${ }^{2}$.

$\mathrm{Na}$ verdade, este convencionalismo, bem representado pela lingüística estruturalista, que abole a centralidade das expectativas referenciais da linguagem na determinação do sentido, seria, aos olhos de Hegel, apenas mais uma figura de um pensar aferrado à gramática da finitude. Gramática que absolutiza o finito e o arbitrário, isto ao mesmo tempo em que bloqueia a possibilidade de uma reflexão sobre o infinito e sobre o que não se submete à perspectiva da arbitrariedade. Por isto, Hegel dirá, nas Lições sobre a Filosofia da religião, que "esta humildade (Demut) é, na verdade, orgulho (Hochmut), pois excluo de mim o Verdadeiro, mas de maneira tal que apenas eu como este deste lado (Dieser im Diesseits) [ou a estrutura 
lingüística no além - neste contexto poderíamos facilmente trocar um termo por outro] sou o afirmativo e ente para-si e em-si, em relação ao qual todo Outro desaparece (verschwindet)" (HEGEL, 2000c, p. 181).

É por não aceitar a falsa humildade da autolimitação de um convencionalismo que se sustenta em uma perspectiva externalista não-assumida que Hegel lembrará: o conceito não é um signo ou mesmo uma representação que subsume a generalidade da experiência à determinação de um genérico lingüístico. Mas a complexidade da posição hegeliana vem do fato de ela não aceitar que o conceito seja, por outro lado, expressão imanente do que ele determina. A noção de imanência não convém à relação hegeliana entre conceito e objeto, ainda que Hegel fale em alguns momentos do saber absoluto como ponto no qual o saber pode "corresponder" (entsprechen) ao objeto. Pois, como veremos, esta correspondência não pressupõe, em absoluto, o recurso a forma alguma de adaequatio.

Qualquer leitor atento da Fenomenologia do Espírito sabe que o movimento dialético é impulsionado, ao contrário, pelo reconhecimento da inadequação reiterada entre conceito e objeto da experiência, entre expectativas organizadoras do conceito e resistência do objeto. Há uma relação de negação entre conceito e objeto. Por outro lado, sabemos que “conceito", em Hegel, não é um operador que se determina a partir da relação biunívoca com um objeto isolado, mas é a formalização de estruturas de relações entre objetos. Por isto, em Hegel, não podemos falar, em última instância, em conceito de objeto, mas em conceito de estados de coisas. Como veremos, a "correspondência" entre conceito e objeto só se dá quando o mesmo regime de negação que determina a confrontação entre conceito e objeto aparecer como processo estruturador de relações internas ao conceito.Veremos, mais à frente, o que isto quer dizer.

\section{A performatividade do conceito e as relações entre linguagem e ação}

Podemos abordar inicialmente, no interior da filosofia hegeliana, este problema da existência de algum regime de imanência entre conceito e objeto a partir de esclarecimentos a respeito da estrutura "performativa" 
do conceito. Lembremos que o conceito hegeliano não é um operador constatativo responsável pela descrição adequada de estados naturalizados de coisas. Na verdade, estaremos mais perto da verdade se dissermos que ele é um operador performativo já que, em última instância e de uma maneira muito peculiar, ele produz a realidade a qual se refere. Em Hegel, há uma performatividade do conceito ligada ao caráter anti-representativo da dialética (GIMMLER, 2004), da mesma forma que há uma arbitrariedade do signo e uma motivação aparente do símbolo.

É neste contexto que podemos melhor compreender por que a primeira tarefa do conceito é a cisão do que aparece como imediato, do que aparece como "representação natural" (natürliche Vorstellung) do pensar. Lembremos, por exemplo, da maneira pela qual Hegel se serve do jogo de palavras entre Urteil (julgamento) e ursprüngliche Teilen (divisão originária), isto a fim de caracterizar a ação do conceito. Maneira de insistir que, na tradição dialética, o conceito não é um operador constatativo por não se adequar ao que estava sempre lá pronto para ser desvelado. $\mathrm{O}$ conceito é um operador performativo no sentido daquilo que instaura um processo, no interior do campo da experiência da consciência, capaz de produzir modificações estruturais na apreensão do mundo posto seja pela certeza sensível, seja pela percepção, seja pelo entendimento. Hegel diz claramente que o conceito cria, e isto em vários momentos da Ciência da lógica. Ele divide o que parecia indivisível (crítica ao princípio de identidade) e unifica o que parecia oposto (através da internalização de negações). É a certeza do caráter performativo do conceito que leva Hegel a afirmar: "Na verdade absoluta [do Espírito] é a mesma coisa encontrar (Vorfinden) um mundo como um pressuposto e produzi-lo (Erzeugen) como algo posto por ele [pelo Espírito]" (HEGEL, 2000, \$386). Poderíamos fornecer aqui uma série de indicadores, no interior dos textos hegelianos, que demonstram claramente o caráter performativo do conceito. Fiquemos aqui, no entanto, apenas com dois que me parecem fundamentais.

Primeiro, temos a noção, fundamentalmente pragmática, de que a verdade é resultado (Resultat) de um processo que se desenrola a partir do campo das experiências lingüísticas ordinárias dos sujeitos. Lembremos como o movimento dialético em direção à posição da afinidade fundamental entre conceito e objeto começa, na Fenomenologia, a partir dos 
impasses da certeza sensível, ou seja, a partir da tematização do processo que se abre através do desdobramento das expectativas que animam usos elementares da linguagem, como a designação ostensiva. De uma certa forma, isto nos lembra, novamente, que a verdade, em Hegel, não é questão de descrição de estados prévios de coisas, mas é: "essência que se realiza (sich vollendende Wesen) através de seu desenvolvimento (Entwicklung)" (HEGEL, 1992a, p. 31; 1988, p. 15). Realização que depende do encaminhamento de problemas que aparece a partir do uso ordinário da linguagem. Desenvolvimento que indica como a verdade não é uma questão de descrição, mas de produção.

Segundo, e este é um ponto fundamental, Hegel expõe claramente a centralidade da relação de proximidade entre linguagem e estruturas da ação; o que aparece, principalmente, através do reconhecimento da proximidade estrutural entre linguagem e trabalho. Podemos insistir nesta proximidade a partir do momento em que aceitamos que a teoria hegeliana do ato (Handlung), com seus desdobramentos necessários em direção à reflexão sobre o trabalho, segue a mesma dinâmica de interversões que a teoria hegeliana da linguagem ou, para ser mais preciso, que a teoria hegeliana da enunciação tal qual ela se encontra em vários momentos da Fenomenologia do espírito (como, por exemplo, nos capítulos sobre $A$ certeza sensivel, sobre $O$ mundo do espirito alienado de si e sobre $A$ consciência moral), assim como nos Princípios da filosofia do direito. Os paradoxos do ato são pensados através dos paradoxos da enunciação e viceversa. Pois: "Linguagem e trabalho são exteriorizações (Äußerungen) nas quais o indivíduo não se conserva mais e não se possui mais a si mesmo; senão que nessas exteriorizações faz o interior sair totalmente de si, e o abandona a Outro" (HEGEL,1992a, p. 198; 1988, p. 208). Neste sentido, podemos esperar, em Hegel, que problemas derivados da teoria da linguagem determinem a configuração das possibilidades da realização da razão em sua dimensão prática. Em última instância, vale para Hegel a idéia de que "uma teoria da linguagem é parte de uma teoria da ação" (SEARLE, 1969, p. 17).

Mas, se voltarmos ao problema da pretensa relação de imanência entre conceito e objeto, veremos que a noção de performatividade não abole necessariamente a pressuposição de tal imanência. Ao contrário, sob um certo aspecto, ela é mesmo sua base, já que o sucesso da performance 
baseia-se, normalmente, na pressuposição de uma sólida identidade entre intencionalidade e força perlocucionária do ato de fala, ou seja, força de modificação de estados de coisas, modificação do campo de experiência no qual sujeitos estão inseridos.

Esta sólida identidade é resultado de uma certa pressuposição. No momento em que se engaja em um ato de fala intencionalmente orientado, o sujeito sempre pode, de direito mas nem sempre de fato, partir da pressuposição prévia de saber o que quer dizer e como deve agir socialmente para fazer o que quer dizer. Em situações de performatividade, o sujeito teria assim uma representação prévia e fundamentada não apenas do conteúdo intencional de seu ato de fala, mas também das condições de satisfação de tal conteúdo. Este último ponto é o mais complexo. Por ser a fala, antes de tudo, um modo de comportamento governado por regras, e como o meu conhecimento sobre falar uma língua envolve, necessariamente, o domínio de um sistema de regras de ação social, seguiria daí que o sujeito que fala teria sempre, de direito e previamente, a possibilidade de saber como tal sistema de regras determina a produção do sentido da ação em geral e dos atos de fala em particular.

Tal pressuposição é uma conseqüência derivada, entre outras coisas, do que está em jogo naquilo que os lingüistas pragmáticos chamam de "princípio de expressibilidade"', com sua definição de que sempre haverá um conjunto de proposições intersubjetivamente partilhadas capaz de ser a exata formulação de um determinado conteúdo intencional. Princípio que vale também para a regulação das expectativas referenciais dos usos da linguagem, já que o fazer referência a algo ou a um estado de coisas implica a capacidade performativa e intencional de identificar este algo através de uma expressão de sentido intersubjetivamente partilhado.

No entanto, e de uma maneira extremamente particular, Hegel parece simplesmente abandonar toda e qualquer forma de princípio de expressibilidade na compreensão do ato de fala que instaura o conceito. De fato, a consciência parte necessariamente da posição prévia de saber o que quer dizer e de como agir socialmente para fazer o que quer dizer. Mas esta posição será sistematicamente intervertida pela dinâmica dos processos de experiência. Hegel diz: "Linguagem e trabalho são exteriorizações nas quais o sujeito não se conserva mais e não se possui mais e si mesmo"; e não algo como: "Linguagem e trabalho são exteriorizações nas quais o 
sujeito expressa conteúdos intencionais e realiza expectativas referenciais”. Há uma razão clara para isto.

Mas poderia parecer que entramos aqui em uma certa contradição. Primeiro, é fato que Hegel pensa a linguagem e seus dispositivos de produção de sentido a partir de uma pragmática própria à fala. Vários comentadores insistiram no fato do movimento próprio à linguagem hegeliana ser o resultado do primado da palavra falada sobre a palavra escrita. Mas, exatamente devido a este primado da fala, não parece que Hegel esteja disposto a abandonar o horizonte regulador do princípio de expressibilidade. Ao contrário, a própria definição canônica da linguagem como: "o ser-aí [ou a presença] do puro Si como Si" (das Dasein des reinen Selbsts, als Selbsts) já parece implicar um privilégio da linguagem como expressão do eu enquanto centro intencional. Daí porque Hegel teria dito: "A linguagem contém o eu em sua pureza, apenas ela enuncia o próprio eu” (HEGEL, 1992b, p. 49; 1988, p. 335). A questão que fica é, então: como a linguagem pode ser a presença do puro Si se ela é uma exteriorização na qual o sujeito não se possui mais a Si mesmo? Uma resposta a tal questão passa, inicialmente, pela compreensão clara das causas deste movimento de despossessão de Si no interior da linguagem.

A fim de analisarmos tal despossessão, vale a pena lembrar que o movimento dialético, tal como ele é apresentado por Hegel, é várias vezes impulsionado a partir de questões pragmáticas como: "o que acontece quando se enuncia o que se quer dizer?" e "o que a consciência realmente faz ao enunciar o que se quer dizer?”.Vários exemplos deste modo de encaminhamento podem ser identificados na obra hegeliana, a começar pelos impasses de enunciação da certeza sensível no início Fenomenologia. Mas pensemos, também, neste momento em que a consciência-de-si assume a figura da sã razão legisladora (gesetzgebende Vernunft) que acredita ter o saber imediato da universalidade da determinação ética e tenta enunciar tal saber, fazendo com isto a experiência de que: "ela falava de outra forma do que pensava (sie sprach anders als sie meinte)" (HEGEL, 1992a, p. 261; 1988, p. 279). Pensemos ainda na Ciência da Lógica, onde é possível ver o mesmo movimento de interversões próprio à enunciação aparecer na crítica ao princípio de identidade $(\mathrm{A}=$ A) e produzir a passagem da negação exterior à negação internalizada. Ao afirmar que a identidade e a diferença são diferentes: "Eles [a consciência 
comum] não vêem que já dizem que a identidade é algo de diverso; pois dizem que a identidade é diversa em relação à diversidade" (HEGEL, 1986b, p. 41). Tais exemplos são o resultado de uma gramática filosófica fundada em considerações particulares sobre a pragmática da linguagem ${ }^{4}$.

Podemos falar em "considerações particulares" porque se trata de um ato de fala que se desconhece enquanto tal, já que a consciência crê servir-se da linguagem para descrever uma realidade imediata e não-problematizada ou para pôr uma certeza imanente. No entanto, ele está produzindo performativamente um movimento de clivagem nesta realidade e nesta certeza. Assim, se há ato de fala em Hegel, ele sempre é, até última ordem, falho, já que a consciência nunca realiza de maneira imediata o que visa, seu conteúdo intencional. Para que ela possa realizar, de maneira bem-sucedida, a "correspondência" entre seu conceito e um estado de coisas determinado, faz-se necessário que a própria compreensão dos modos de relação entre conceito e efetividade sejam reconfigurados, já que eles não vão mais poder ser pensados a partir de noções não-dialéticas como "subsunção" ou "aplicação".

Partamos, pois, de uma hipótese maior: os modos de relação entre conceito e estado de coisas, em Hegel, só serão visíveis à luz da identificação de que o motor da dialética é a experiência da impossibilidade de convergir, de maneira imediata, designação (Bezeichnung) e significação (Bedeutung) no ato de fala ${ }^{5}$. Assim uma reflexão sobre a linguagem em chave dialética deve partir da tentativa de compreensão das razões que levaram Hegel a colocar a experiência deste descompasso como a verdadeira célula elementar reguladora dos usos da linguagem.

\section{Designar e significar}

Voltemos aqui os olhos para o início da Fenomenologia do Espírito, ou seja, para esta descrição da experiência da consciência em direção ao Absoluto que começa com a exposição de um problema lingüístico ligado à natureza do que podemos chamar de "designação ostensiva". Chamamos de "designação ostensiva" a tentativa de fundar a significação de um termo através da indicação referencial de um caso empírico que determinaria a extensão do uso do referido termo. Ou seja, trata-se de tentar 
definir a significação através da indicação da referência. De uma certa forma, todo capítulo inicial sobre a certeza sensível é uma longa reflexão sobre a impossibilidade de designações ostensivas e a conseqüência disto para a compreensão da maneira pela qual o conceito pode reconciliar-se com a Coisa. Notemos, por outro lado, este dado fundamental: não é por acaso que a dialética começa necessariamente através de uma reflexão sobre a relação entre as palavras e as coisas. Trata-se de mostrar como a dialética é dependente de um questionamento a respeito dos modos de funcionamento da linguagem em suas expectativas referenciais, ela nasce através deste questionamento e da maneira como tal problematização das expectativas referenciais da linguagem nos obriga a rever conceitos ontológicos centrais.

Vejamos, pois, como tal problematização é inicialmente apresentada. Sabemos que a consciência crê ter a intuição imediata do ser. Ela crê também poder mostrar tal intuição através de uma designação. Eis porque Hegel afirma: devemos perguntar à consciência "o que é o isto (Was ist das Diese)?":

Se o tomarmos na dupla forma (Gestalt) de seu ser, como o agora e como o aqui, a dialética que tem nele vai tomar uma forma tão inteligível quanto o ser mesmo. À pergunta: o que é o agora?

Respondemos com um exemplo (Beispiel): o agora é a noite. Para tirar a prova da verdade dessa certeza sensível basta uma experiência simples. Anotamos por escrito essa verdade; uma verdade nada perde por ser anotada, nem tampouco porque a guardamos. Vejamos de novo, agora, neste meio-dia, a verdade anotada; devemos dizer, então, que se tornou vazia. O agora que é noite foi conservado (aufbewahrt), isto é, foi tratado tal como se ofereceu, como um ente (Seiendes); mas se mostra, antes, como um não-ente. O próprio agora, bem que se mantém, mas como um agora que não é noite. Também em relação ao dia que é agora, ele se mantém como um agora que não é dia, ou seja, mantémse como um negativo em geral (...) Nós denominamos um universal um tal Simples que é por meio da negação; nem isto nem aquilo - um não-isto, e indiferente também a ser isto ou aquilo. $\mathrm{O}$ universal portanto é, de fato, o verdadeiro da certeza sensível (HEGEL, 1992a, p. 76; 1988, p. 71). 
O que esta passagem quer dizer? Primeiro, notemos como Hegel introduz o problema da designação a partir da dupla forma da intuição, ou seja, o espaço (aqui) e o tempo (agora). Trata-se assim de, primeiramente, compreender o que acontece a uma Coisa quando a intuímos no espaço e no tempo. Hegel nos fornece o exemplo da intuição dos momentos no tempo, é ela que lhe serve de paradigma.

Intuir algo no tempo é ter a experiência de que há algo diante de mim agora. No entanto, o agora não é modo de presença do singular visado. De uma certa forma, o agora é o nome que indica a negação de todos os instantes. Posso tentar designar este instante afirmando: "Este instante é o agora", no entanto, o agora deixa de ser enquanto era indicado, ele passa diretamente para a referência de outro instante. Ele, no entanto, não é a designação do outro-instante, mas apenas a forma da passagem incessante no outro. É isto que Hegel tem em mente ao afirmar que agora é, na verdade, a forma do "negativo em geral"; figura do negativo que deve ser compreendida como a manifestação do que não pode ser a determinação que se põe no isto ou no aquilo, mas "não-isto (nicht dieses)". Por isto, podemos dizer que o agora é a forma do desvanecimento de todo instante. Intuir objetos no tempo é assim ter a experiência do que só é não sendo - segundo a proposição hegeliana: "o tempo é aquilo que, não sendo, é” (HEGEL, 2000, \ 448). Isto implica um modo de presença não mais assentado no primado da visibilidade do que se oferece no espaço.

Assim, lá onde a consciência sensível acreditava designar a particularidade irredutível do instante, deste instante do qual só podemos dizer que ele é o agora, ela estava, na verdade, tendo a experiência do descompasso incessante entre a significação do agora e a designação do instante. Experiência da impossibilidade de designar a particularidade do instante. Eis porque Hegel pode afirmar que a consciência, ao tentar enunciar a particularidade, apenas tinha a experiência de estar enunciando a universalidade que se abstrai de todo particular, sendo que "universalidade" é inicialmente sinônimo de "abstração". Ao tentar designar o sensível, a consciência apenas fez a experiência de só poder enunciar o puramente abstrato. Esta experiência ganhará o valor de exposição da exterioridade irredutível da designação à significação que aparece como motor da dialética. E então Hegel pode completar: 
Enunciamos também o sensível como um universal. O que dizemos é: isto, quer dizer, o isto universal; ou então: ele é, ou seja, o ser em geral. Com isto, não nos representamos, certamente, o isto universal, ou o ser em geral [pois não tenho a extensão de todos os objetos que caem sob o isto ou sob o $\quad s e r]$, mas enunciamos o universal; ou, por outra, não falamos pura e simplesmente tal como nós o visamos na certeza sensível. Mas, como vemos, o mais verdadeiro é a linguagem: nela refutamos imediatamente nosso visar, e porque o universal é o verdadeiro da certeza sensível, e a linguagem só exprime esse verdadeiro, está pois totalmente excluído que possamos dizer o ser sensível que visamos [assim como está excluído que possamos fundar a significação em uma designação ostensiva] (HEGEL, 1992a, p. 76; 1988, pp. 71-72).

Por um lado, Hegel não faz outra coisa que aproveitar aqui a característica de dêitico (ou de shifter) de termos como "agora" "isto", "eu"6. Tais termos têm um modo particular de funcionamento porque são unidades gramaticais que não podem ser definidas fora da referência a uma mensagem e, por conseqüência, ao ato de enunciação. A natureza dos shifters é dupla. De um lado, eles funcionam como símbolo devido a sua relação convencional à referência. Por outro lado, eles funcionam como índex devido a sua relação existencial à referência particularizada pelo contexto.

Este uso dos shifters não deveria, no entanto, nos colocar maiores problemas. Ele deveria apenas nos mostrar como precisamos estruturar contextos para compreender o sentido de designações ostensivas. Mas Hegel tira daí uma série de conseqüências importantes. Primeiro, a necessidade de atualizar o contexto de enunciação apenas mostra como devemos pressupor estruturas de relações antes de qualquer tentativa de designação. Se digo, que para entender "O que é o isto?", preciso atualizar contextos, então isso significa que preciso mostrar como o "isto" está "em relação a ...", como o "agora" é "agora em relação a ...". Preciso saber diferenciar e comparar situações, ou seja, preciso ter diante de mim todo o sistema de organização simbólica que estrutura a linguagem. Chegamos assim à idéia paradoxal de que preciso operar mediações complexas para dar conta do que aspira a aparecer como puramente imediato. Hegel sabe que as coordenadas que identificam o lugar lógico do ato de indicação são, 
desde o início, articuladas no interior de uma estrutura de relações dada como condição a priori para a experiência. O que vemos quando ele afirma, por exemplo, que:

$\mathrm{O}$ aqui indicado, que retenho com firmeza, é também um este aqui que de fato não é este aqui, mas um diante e atrás, um acima e abaixo, um à direita e à esquerda. O acima, por sua vez, é também este múltiplo serOutro, com acima, abaixo etc. $\mathrm{O}$ aqui que deveria ser indicado desvanece em outros aqui, mas esses desvanecem igualmente. $\mathrm{O}$ indicado, o retido, o permanente é um este negativo que só é tal porque os aquis são tomados como devem ser, mas nisso se supera, constituindo um complexo simples de muitos aqui (einfache Komplexion vieler Hier) (HEGEL, 1992a, p. 80; 1988, pp. 75-76).

Hegel está simplesmente dizendo que não há singularidade que não passe a priori pelo genérico da estrutura, já que toda indicação é feita em um tempo e em um espaço estruturalmente coordenados. Tudo se passa como se Hegel, a sua maneira, houvesse percebido o problema de Quine sobre a inescrutabilidade da referência. Lembremos como Quine nos afirma que: "A referência é sem sentido exceto em relação a um sistema coordenado (...) Indagar pela referência de algum modo mais absoluto seria como perguntar pela posição absoluta, ou pela velocidade absoluta, antes que pela posição ou velocidade relativa a um quadro de referência dado" (QUINE, 1980, p. 145). Isto permite a Quine deduzir que ser é ser valor em uma variável, o que nos leva a uma relativização da ontologia.

Hegel, de sua parte, compreende inicialmente o resultado como a experiência do fracasso da apresentação positiva imediata do acontecimento singular (ou da referência enquanto ser sensível). A instância singular referida não acede à palavra, embora, como veremos, sua dignidade ontológica não seja simplesmente anulada ${ }^{7}$.

Mas notemos um ponto fundamental que diz respeito ao destino da referência. Ao afirmar que está excluído que possamos dizer o ser sensível, parece que Hegel nos leva a afirmar que a linguagem não pode dar conta de maneira satisfatória do problema da referência, a não ser que admitamos que a referência é sem sentido, salvo em relação a um sistema diferencial de coordenadas. Poderíamos deduzir assim que há uma arbitrariedade fundamental da linguagem, vinculada à abstração necessária da 
linguagem em relação ao sensível, que nos impede de estabelecermos relações com a Coisa, como no caso do signo.

No entanto, a tentativa de recuperar o que inicialmente aparece como exterioridade do sensível em relação ao sistema lingüístico de diferenças e oposições será o motor da dialética. Como vemos, a questão aqui é: “como a linguagem pode recuperar o que ela perde por operar?". Tal recuperação exige uma certa re-orientação da ontologia ${ }^{8}$.

Neste ponto, faz-se necessário um desdobramento. O problema levantado pela tentativa de designação da singularidade ancorada no sensível não se esgota na compreensão da impossibilidade da realização das expectativas que guiavam a certeza sensível. $\mathrm{Na}$ verdade, esta é apenas a figura inicial de um problema que aparecerá de maneira reiterada no interior da filosofia hegeliana e que diz respeito aos modos de encaminhamento da dialética entre, de um lado, regras, sistemas e modos de estruturação de relações que aspiravam validade universal e, de outro, casos empíricos particulares capazes de determinar conteúdos. Dialética relativa à determinação de modos fundamentados de indexação entre regra e caso que será constantemente mobilizada por Hegel na problematização das condições de possibilidade de realização das aspirações práticas da razão. Daí porque Robert Brandom está correto em salientar que, com Hegel: "o problema do entendimento da natureza e das condições de possibilidade (no sentido de inteligibilidade) de normatividade conceitual [ou seja, do conceito como norma que traz, em si, o modo de determinação dos casos que caem sob sua extensão] move-se para o centro" (BRANDOM, 2002, p. 212).

\section{0 background do Espírito}

Mas sabemos que problemas desta natureza podem ser resolvidos através de um apelo àquilo que lingüistas pragmáticos chamam simplesmente de background, ou seja, um conjunto de saberes prático-sociais pré-intencionais que orientam sujeitos no uso cotidiano da linguagem e na realização das condições de satisfação de seus conteúdos intencionais. E, de fato, parece que é algo parecido com isto que Hegel tem em mente através de seu conceito de Espírito (Geist). 
Quando Hegel fala em Espírito, podemos compreender isto, a princípio, de uma maneira não-metafisica. Atualmente, quando falamos sobre sujeitos socializados que procuram julgar, orientar racionalmente suas ações e usos da linguagem, lembramos inevitavelmente da necessidade de um background pensado um "sistema de expectativas" fundamentado na existência de um saber prático cultural e de um conjunto de pressupostos que define, de modo pré-intencional, o contexto de significação. Este background indica que toda ação e todo julgamento pressupõem um "espaço social partilhado" capaz de garantir a significação da ação, do julgamento e, principalmente, de nossos modos de estruturar relações.

Como disse, este background é, em larga medida, pré-intencional e préreflexivo. Não colocamos normalmente a questão sobre a gênese deste saber prático cultural que fundamenta nossos espaços sociais. Sua validade não aparece como objeto de problematização. No entanto, podemos imaginar uma situação na qual os sujeitos socializados procuram apreender de maneira reflexiva aquilo que aparece a eles como fundamento para suas práticas e julgamentos racionais, podemos pensar uma situação na qual eles procurem compreender o processo de formação cultural que os levou a tais modos de orientação racional da conduta. Podemos ainda achar que tais modos de orientação não devem ter apenas uma validade historicamente determinada e restrita a espaços sociais particulares, mas só podem ser válidos se puderem ser defendidos enquanto universais. Neste momento, estaremos muito próximos daquilo que Hegel compreende por Espírito. Devemos, neste ponto, seguir a definição de um comentador de Hegel que viu claramente isto: "Espírito é uma forma de vida autoconsciente, ou seja, uma forma de vida que desenvolveu várias práticas sociais a fim de refletir a respeito do que ela toma por legítimo/válido (authoritative) para si mesma no sentido de saber se estas práticas podem dar conta de suas próprias aspirações e realizar os objetivos que elas colocaram para si mesmas (...) Espírito não denota, para Hegel, uma entidade metafisica, mas uma relação fundamental entre pessoas que medeia suas consciências-de-si, um meio através do qual pessoas refletem sobre o que elas tomaram por válidos para si mesmas" (PINKARD, 1994, p. 9).

No entanto, dizer isto ainda é, no caso de Hegel, dizer pouco. Pois Hegel acredita que este solo de práticas sociais que pode ser apropriado 
de maneira reflexiva pelos sujeitos nele enraizados não é simplesmente o resultado de contingências sócio-históricas. Ele só pode ser apropriado de maneira reflexiva quando os sujeitos forem capazes de conceitualizar a racionalidade da "necessidade lógica" do trajeto que constitui o Espírito. E esta necessidade só será visível a partir do momento em que o sujeito apreender a especificidade da forma estrutural de relações tecidas pelo Espírito. Pois o Espírito só se manifesta a partir do momento em que os sujeitos se desesperam dos modos de estruturar relações, baseados em noções não-dialéticas de identidade e diferença. É neste ponto que devemos fazer apelo à teoria hegeliana das negações.

\section{Construindo relações através da negação determinada}

Vimos anteriormente como, para Hegel, as coordenadas que identificam o lugar lógico do ato de designação são, desde o início, articuladas no interior de uma estrutura de relações dada como condição para a experiência. A consciência que procura realizar a designação crê que ela é capaz de pôr imediatamente a auto-identidade por ignorar que tal identidade é apenas um momento da diferença constituído a partir de relações estruturadas de negações entre termos. De uma certa forma, o problema da certeza sensível nos mostra que enunciar a identidade é enunciar que a coisa ocupa um lugar em um sistema lingüístico de determinações, não tendo sua identidade em si mesma, mas em um sistema de relações.

De fato, não há experiência que não seja nomeada em uma linguagem cuja dinâmica obedeça a leis de estrutura. No entanto, a apreensão do conteúdo em um sistema estruturado próprio ao saber da consciência deve necessariamente produzir um resto cujo destino coloca, até aqui, problemas. E se, na Lógica da essência, a determinação-de-reflexão própria à identidade é superada pela diversidade (Verschiedenheit), é porque se trata de criticar o pensamento da identidade inicialmente através do recurso à irredutibilidade do múltiplo próprio ao diverso da experiência.

Tentemos compreender esta característica "clivada" da experiência hegeliana através de um desvio. Omni determinatio est negatio, dizia Espinosa. A afirmação caracteriza bem o primeiro nível de engendramento da identidade a partir de oposições. Se quisermos continuar no terreno 
de uma comparação posta no início deste artigo, esta fórmula pode também ser deduzida do caráter estrutural da lingüística de Saussure. Se a identidade é, como dirá Hegel várias vezes, “o outro do outro” é porque a produção de determinações é um fato de estrutura. Tanto a dialética quanto o estruturalismo são inicialmente pensamentos da relação ${ }^{9}$.

Para o lingüista, um significante só recebe seu valor através de sua relação diferencial e opositiva com os outros significantes de um sistema lingüístico dado: "na língua, só há diferenças" (SAUSSURE, 1972, p. 166).A característica mais determinante de um significante é ser o que os outros não são, ou seja, ser outro do outro. Neste sentido, é a oposição que permite, inicialmente, a estruturação de processos de identificação. Podemos afirmar que, tanto para Saussure quanto para Hegel: "a identidade de uma entidade consiste em um conjunto de seus traços diferenciais" (ZIZEK, 1999, p. 135). Pois, para Hegel:"a identidade e a diferença são momentos da diferença sustentados no interior dela mesma: elas são momentos refletidos de sua unidade" (HEGEL, 1986b, p. 55).

No entanto, há aqui, ao menos duas diferenças cruciais. A primeira toca a articulação entre estrutura de relações e referência. A segunda, diz respeito à distinção entre oposição e negação determinada como procedimentos de identificação e determinação de identidades, já que, para Hegel, "negação determinada" é o nome do processo que permite a estruturação de relações dialéticas. Comecemos, pois, pelo segundo ponto.

Retornemos primeiramente à hipótese do holismo semântico, ou seja, esta noção de que, em Hegel, a compreensão das relações entre objetos é condição suficiente para a determinação do conteúdo da experiência. Uma primeira leitura deste holismo parece indicar que o saber absoluto hegeliano seria a realização da adequação total do conceito (compreensão de relações - lembremos que, para Hegel, o conceito não é subsunção do diverso da experiência sob a forma de objeto, mas posição de estruturas de relações) ao objeto (o conteúdo da experiência); isto se ele não fosse simplesmente a implementação de um convencionalismo que afirma ser o conteúdo da experiência apenas aquilo que pode se adequar à estruturação de relações.

No entanto, Hegel insiste que tanto a adequação entre conceito e objeto quanto a estruturação de relações internas ao conceito só serão 
possíveis sob a condição de compreendermos como as relações são estruturadas a partir de negações determinadas, e não a partir de oposições.

A princípio a definição de "negação determinada" é mais trivial do que parece. Tomemos, por exemplo, duas proposições negativas:

- A mulher não é alta

- A mulher não é homem

Percebemos claramente que há aqui dois usos distintos da negação, um uso indeterminado e um uso determinado. Eles são resultados de dois modos distintos de uso do verbo "ser": um como predicação e outro como posição de identidade. A negação que incide sobre o verbo ser no interior de uma relação de predicação é indeterminada. A negação de um termo não me dá automaticamente o outro termo. Não posso passar de "mulher" para "alta" e vice-versa. Já a negação que incide sobre o verbo ser no interior de uma relação de identidade é determinada. A negação de um termo me faz passar automaticamente a um outro termo, neste sentido, a negação "conserva" o termo que ela nega. No nosso exemplo, a negação do sujeito gramatical "mulher" me faz necessariamente passar ao termo posto no predicado. Isto porque, ao negarmos o verbo ser no interior de uma relação de identidade, estamos necessariamente estabelecendo uma relação de "oposição" ou de "contrariedade". "Passar de um termo a outro", para usar uma expressão hegeliana, indica aqui a existência de uma relação de solidariedade entre dois termos contrários: homem e mulher, Um e múltiplo, ser e nada. O Um é inicialmente negação do múltiplo, o ser é inicialmente negação do nada. Isto nos mostra que uma determinação só pode ser posta através da oposição, ou seja, ela deve aceitar a realidade de seu oposto. A positividade da identidade a si é suportada pela força de uma negação interna que, na verdade, sempre pressupõe a diferença pensada como alteridade.

Assim, quando dizemos: a negação determinada é aquilo que permite, ao conceito, estruturar relações de objetos, parece que estamos dizendo, simplesmente, que toda relação capaz de determinar identidades é necessariamente uma relação de oposição. Poderíamos mesmo dizer, com Deleuze, que: "Hegel determina a diferença por oposição dos extremos ou dos contrários" (DELEUZE, 2000, p. 64), como se toda diferença essencial pudesse ser submetida a relações de oposição. Falar de uma negação que conserva o termo negado seria simplesmente uma maneira 
mais nebulosa de dizer que, em toda relação de oposição, a posição de um termo pressupõe a realidade de seu oposto como limite à sua significação. Neste sentido, poderíamos compreender tentativas, como a de Robert Brandom, de definir a negação determinada como a simples reflexão sobre as conseqüências de assumirmos o caráter estruturante de relações de incompatibilidade material. Lembremos do que ele afirma:"Hegel aceita o princípio medieval (e espinosista) omni determinatio est negatio. Mas a mera diferença ainda não é a negação que a determinidade exige de acordo com esse princípio. Essencialmente, a propriedade definidora da negação é a exclusividade codificada no princípio de não-contradição: $p$ exclui-se de não-p; eles são incompatíveis" (BRANDOM, 2002, p. 179). Assim: "o conceito de incompatibilidade material ou, como Hegel o designa, de 'negação determinada' é seu mais fundamental instrumento conceitual” (BRANDOM, 2002, p. 180).

No entanto, esta compreensão da negação determinada como figura da oposição é falha sob vários aspectos. Ela é útil para nos lembrar como a negação pode estruturar relações conceituais, mas ela não dá conta de alguns pontos centrais. O principal deles diz respeito ao fato de, como veremos mais adiante, Hegel construir a noção de negação determinada exatamente como dispositivo de crítica à idéia de que as oposições dão conta da estruturação integral das relações. Pois a oposição pode admitir que só é possível pôr um termo através da pressuposição da realidade do seu oposto, que aparece aqui como limite de significação. Mas a oposição não pode admitir que a identidade de um termo é a passagem no seu oposto, que o limite de um termo, por ser seu limite, faz parte da extensão do próprio termo. No entanto, a negação determinada significa exatamente isto: que o termo, ao realizar-se, ou seja, ao se referir à experiência, passa necessariamente no seu oposto e esta passagem é, ao mesmo tempo, a perda do seu sentido e a realização do seu sentido ${ }^{10}$.

A princípio, nada disto parece ter muito sentido, já que se trata de problematizar a própria noção de "relação". De fato, nesta perspectiva, a noção de negação determinada parece naturalmente obscura. Afinal, como é possível dizer que a realização de um termo, no sentido de sua determinação referencial através da experiência, é uma passagem no oposto, é o reconhecimento de sua identidade com aquilo que o nega? 


\section{Duas (ou três) negações: entre oposição real e contradição}

Responder tal questão exige que entremos, de maneira explícita, no comentário da articulação hegeliana entre teoria das negações e ontologia. O primeiro passo para tal entrada pode ser dado através de um esforço de precisão. Quando falamos sobre modos de negação em Hegel, não devemos esquecer que o pensamento especulativo conhece dois níveis distintos (e mesmo três) de negação: a negatividade abstrata (abstrakte Negativität) que às vezes aparece sob o nome de negação simples (einfache Negation) e a negatividade absoluta (absolute Negativität) que às vezes aparece sob o nome de negação da negação: resultado especulativo de uma negação determinada. No interior da negatividade absoluta, podemos determinar ainda dois outros níveis de negação representados pelas interversões próprias à Umschlagen (ou pelas inversões próprias à Verkehrung) e pela superação própria à Aufhebung. É possível que uma negação que se queira dialética bloqueie-se no primeiro nível, ou seja, pode haver interversões e inversões sem resoluções dialéticas. No entanto, não pode haver resoluções dialéticas sem interversões ou inversões.

Estes dois sistemas maiores de negação articulam-se com as noções de oposição real (Realentgegensetzung e também Realopposition), tal como Kant a desenvolveu em seu Ensaio para introduzir em filosofia a noção de grandeza negativa, e de contradição (Widerspruch), tal como Hegel a concebe.

Sobre a negação abstrata, podemos dizer inicialmente que ela se define por seu caráter de delimitação de uma determinidade através da exclusão para fora de si de toda alteridade. Neste sentido, ela permite que uma determinidade ponha sua identidade através de relações de oposição. Assim, por exemplo, na proposição: "O individual não é o Universal”, a negação aparece como operação que permite ao sujeito gramatical estabelecer seu limite e sua identidade através da oposição ao predicado.

Segundo Hegel, ao pôr as determinações opostas como exteriores, a negação abstrata estabelece necessariamente uma relação de correspondência entre referência e conceito. Ela nega a solidariedade reflexiva com o oposto, fixando as determinações como se estas fossem expressões de diferenças naturalizadas. Mas, ao mesmo tempo, ela nega a diferença entre a referência e seu conceito. 
Sobre o primeiro movimento próprio à negação abstrata (a delimitação da determinidade através da exclusão para fora de si de toda alteridade), devemos lembrar que Hegel desenvolve suas considerações tendo em vista, principalmente, o conceito kantiano de oposição real. Para Kant, uma oposição real indica que dois predicados de um sujeito são opostos de maneira contrária, mas sem contradição lógica. Assim: "a força motriz de um corpo que tende a um certo ponto e um esforço semelhante deste corpo para se mover em direção oposta não se contradizem, sendo ao mesmo tempo possíveis como predicados de um mesmo corpo" (KANT, 2005, p. 58). Tal oposição é descrita em linguagem matemática através dos signos $+\mathrm{e}-(+\mathrm{A}$ e $-\mathrm{A})$ a fim de mostrar como uma predicação pode destruir outra predicação, chegando a uma conseqüência cujo valor é zero, mas sem que seja necessário admitir um conceito que se contradiz em si mesmo (nihil negativum). Isto permitirá a Kant sublinhar que o conflito resultante de um princípio real que destrói o efeito de outro princípio no nível da intuição não pressupõe uma contradição no nível das condições transcendentais de constituição do objeto do conhecimento. Este conflito real, ou oposição real, é a boa negação; "que permite ao entendimento constituir objetos”(DAVID-MÉNARD, 1990, p. 41), já que, contrariamente à contradição lógica (pensada como objeto vazio sem conceito), esta negação deixa fora de seu julgamento a questão da existência do sujeito do julgamento.

Mas, se Kant afirma que os predicados opostos são contrários sem serem contraditórios, é porque eles se misturam como forças positivas determinadas no resultado de uma realidade final. Os opostos reais são, para Kant, propriedades igualmente positivas, eles correspondem a referências objetivas determinadas. Não há realidade ontológica do negativo (mesmo se há um poder negativo do transcendental na determinação do númeno como conceito vazio em relação à intuição de objetos sensíveis). A aversão e a dor são tão positivas (no sentido de se referirem a objetos positivos) quanto o prazer. Elas têm uma subsistência positiva como objetos sensíveis que não é redutível à relação de oposição.

Hegel está atento ao modo como a oposição real não modifica a noção de determinação fixa opositiva. Mesmo reconhecendo a existência de uma solidariedade entre contrários no processo de definição do sentido dos opostos (ao afirmar que "a morte é um nascimento negati- 
vo", Kant reconhece que o sentido da morte depende da determinação do sentido do nascimento), a noção de oposição nos impede de perguntar como a identidade dos objetos modifica-se quando o pensamento leva em conta relações de oposição ${ }^{11}$. Como nos diz Lebrun: "Que cada um dos termos só possa ter sentido ao ligar-se ao seu oposto, isto o Entendimento concede, esta situação é figurável. Mas que cada um advenha o que significa o outro, aqui começa o não-figurável" (LEBRUN, 1971, p. 292). Eis por que: "Mesmo admitindo, contra os clássicos, que o positivo pode se suprimir e que o negativo possui de alguma maneira um valor de realidade, Kant jamais colocará em questão o axioma: 'A realidade é algo, a negação não é nada'. Essa proposição é até mesmo a base do escrito sobre as grandezas negativas: ela é a condição necessária sem a qual não se poderia discernir a oposição lógica da oposição real” (LEBRUN, 2002, p. 266).

Neste sentido, podemos dizer que Hegel procurar desdobrar todas as conseqüências possíveis de um pensamento da relação assentado na centralidade de negações determinadas. Pois a produção da identidade através da mediação pelo oposto, tal como vemos na oposição real, é reflexão-no-outro. Um recurso à alteridade que aparece como constitutivo da determinação da identidade que promete uma interversão (Umschlagen) da identidade na posição da diferença. Como nos dirá Henrich, o primeiro passo deste movimento dialético consiste em passar de algo que se distingue do outro enquanto seu limite para algo que é apenas limite (HENRICH, 1967, p. 112). Tal passagem torna-se possível porque Hegel submete a negação funcional-veritativa à noção de alteridade, seguindo aí uma tradição que remonta ao Sofista, de Platão12: "Contrariamente à negação funcional-veritativa [fundada na idéia de exclusão simples], a alteridade é uma relação entre dois termos. São necessários ao menos dois termos para que possamos dizer que algo é outro" (HENRICH, 1967, p. 133).

Tal submissão da negação à alteridade nos explica porque a figura maior da negação em Hegel não é exatamente o nada ou a privação, mas a contradição ${ }^{13}$. Contradição que aparece quando tentamos pensar a identidade em uma gramática filosófica que submete a negação à alteridade. Nesta gramática, só há identidade quando uma relação reflexiva entre dois termos pode ser compreendida como relação 
simples e auto-referencial, ou seja, só há identidade lá onde há reconhecimento reflexivo da contradição.

Poderíamos assim pensar que a negação absoluta, ou a dupla negação, seria simplesmente a afirmação desta identidade entre os contrários ou deste: "desvanecimento (Verschwinden) incessante dos opostos em si mesmos" (HEGEL, 1986b, p. 67). Mas afirmar isto equivale a confundir a Umschlagen própria a tais passagens no contrário com a Aufhebung que funda a negação absoluta como negação: "que suprime de tal maneira que conserva (aufbewarht) e retém (erhält) o que é suprimido". "Conservação" e "retenção" são dois termos que demonstram como a Aufhebung é, em um certo nível, modo de negação que opera supressões exatamente para poder bloquear as interversões e para poder pôr na efetividade uma determinação sem invertê-la em seu contrário.

Isto é possível porque, contrariamente à negação abstrata, a negação absoluta própria à Aufhebung não é expulsão do oposto, ainda que não seja também uma simples passagem no oposto. Ela é apresentação do que não pode ser posto imediatamente de maneira positiva pelo conceito. Neste sentido, seu problema consiste em conseguir conservar em uma determinação de objeto o que é negação ontológica.

Tal negação ontológica, negação que apresenta o que é em-si negativo, manifesta-se sempre através do caráter evanescente (Vergehen), através do desvanecimento (Verschwinden) da referência diante das operações do conceito. É neste sentido que podemos compreender a afirmação de Adorno: "Como cada proposição singular da filosofia hegeliana reconhece sua própria inadequação (Unangemessenheit) à unidade, a forma exprime então tal inadequação na medida em que ela não pode apreender nenhum conteúdo de maneira plenamente adequada" (ADORNO, 1999, p. 328). Mas este bloqueio na apreensão do conteúdo é um fato inscrito na linguagem especulativa: "Se se diz também", dirá Hegel, "o efetivo é o Universal (das Wirkliche ist das Allgemeine) [e, para Hegel, todo processo de nomeação passa por esta dialética entre o particular e o universal, nomear é relacionar-se a um particular através do universal da linguagem], o efetivo como sujeito desaparece (vergeht) em seu predicado" (HEGEL, 1992a, p. 56; 1988, p. 47). A negação dialética se desdobrará exatamente como o reconhecimento deste caráter evanescente da referência. Podemos mesmo dizer que a linguagem especulativa é, de 
uma certa forma, linguagem do evanescimento: linguagem que não petrifica suas afirmações, mas que apresenta a referência no momento de seu passar ao limite.

Assim, contrariamente ao arbitrário da relação signo/referência, a natureza evanescente da referência em Hegel significa admitir uma modalidade possível de relação entre palavra e coisa através de uma negação pensada como modo de presença. Esta é uma perspectiva que Saussure não parece pronto a aceitar, sobretudo quando afirma que a especificidade dos objetos da ciência da linguagem consiste: "no fato dos objetos que ela tem diante de si não terem jamais realidade em si, ou à parte dos outros objetos a considerar; eles não têm absolutamente substratum algum à sua existência fora de suas diferenças ou de qualquer diferença que o espírito encontra meio de vincular à diferença fundamental" (SAUSSURE, 2002, p. 63). Na verdade, a gramática hegeliana nunca negou a existência de um gênero de 'realidade em si' dos objetos nomeados pela linguagem; mas ela nunca se viu obrigada a pôr um substrato pré-discursivo como recurso ao pensamento. $\mathrm{O}$ em si do objeto não é um dado positivo, mas é negação em si. Graças a isto, a idéia de um caráter evanescente da referência porta em si uma certa modalidade de presença própria a esta noção hegeliana da temporalidade como atividade negativa ideal.

Este ponto é fundamental para compreender a natureza da dupla negação em Hegel. A primeira negação é inadequação entre a estrutura lingüística do pensamento e o objeto da experiência. Através de considerações sobre a designação em Hegel, é possível apreender tal inadequação como negação que vem do fracasso do ato de indicar. Fracasso que aparece como evanescimento da referência no interior do sistema lingüístico produtor de significação. A interversão dialética feita através da negação da negação consiste em ver no vazio do evanescimento um modo de significação do individual. A negação que vem da designação e que indica o evanescimento da referência é repetida de maneira invertida: o evanescimento da referência nega a significação produzida pela estrutura. A primeira negação vai da palavra às coisas e é própria ao signo; a segunda, das coisas à palavra e é colocada em operação pelo trabalho do conceito.

Este movimento duplo nos permite afirmar que a linguagem em Hegel não é nem convencionalista (entre a palavra e a coisa só haveria 
relações arbitrárias - posição mais próxima de Saussure), nem expressiva (a palavra seria presença da coisa, como se existisse um hilomorfismo entre forma e conteúdo). Pois, como nos lembra Lebrun: "A expressão? O conceito não se exprime nem se indica através de suas determinações: ele se mostra dissolvendo-as e negando-lhes a independência aparente" (LEBRUN, 1971, p. 353). Para a dialética, não há expressão que não seja negação do expresso. Se o evanescimento pode produzir significação é porque o pensamento especulativo desenvolve o que Ruy Fausto chamou de "significações-limites": significações que se dão no limite da passagem de um termo a outro.

Neste sentido, a reconciliação hegeliana trazida por um conceito que é negação da negação não é simples posição de uma afirmação, construção da reconciliação a partir da lógica da adequação. Ela é reconhecimento lingüístico da essência dos objetos como negação em si. Aqui, aparece mais claramente o que determina o regime de relação entre linguagem e ontologia em Hegel. A realidade ontológica da negação (que deve se manifestar no campo da experiência no momento em que o que é "mero conceito" procura indexar a efetividade) orienta a linguagem em suas expectativas referenciais. Isto implica um conceito capaz de recuperar (no sentido de internalizar) o que foi negado de maneira abstrata pelo signo e que, a partir desta internalização, seja capaz de reconfigurar os regimes de relação entre termos. Uma das dimensões deste trabalho de internalização do que é em-si negativo nos leva a compreender o conceito como aquilo capaz de formalizar o que podemos chamar de contradição objetiva.

\section{A contradição objetiva entre Hegel e Adorno}

Contradição objetiva: não é um termo que encontraremos em Hegel, já que foi forjado pela tradição dialética de orientação marxista a fim de sublinhar o caráter real, e não simplesmente lógico, da contradição dialética. Críticos da dialética vêem, no conceito de contradição objetiva, um gênero de 'monstruosidade conceitual' que seria resultante de uma confusão mais ou menos ingênua entre oposição real e oposição lógica. No entanto, ela é uma noção fundamental para compreendermos como o conceito internaliza aquilo que o nega. 
Para compreender a contradição objetiva, parece-me que é necessário partir da afirmação hegeliana: "Algo é vivente apenas na medida em que contém em si a contradição (Widerspruch in sich enthält) e é esta força [que consiste] em apreender em si e a suportar a contradição" (HEGEL, 1986b, p. 76). Mas o que pode significa a noção de conter em si a contradição? Sigamos uma indicação de Adorno: "o caráter objetivo da contradição (objektive Widersprüchlichkeit) não designa apenas o que do ente (Seienden) fica exterior ao julgamento, mas, ao contrário, algo no próprio julgado (...) trata-se de prosseguir, no conhecimento, a inadequação entre o pensamento e a coisa (Sache), de experimentá-lo na coisa" (ADORNO, 1973, p. 152). Experimentar na coisa a inadequação entre o pensamento e a realidade empírica só pode significar mostrar, no interior do objeto da experiência, a defasagem entre signo e designado como modo de manifestação da essência do que se coloca como objeto.

Lembremos do que diz Adorno a respeito da dupla negação produzida a partir da negação determinada: "a negação da negação não cancela (rückgängig) esta negação [primeira], mas revela que ela não era suficientemente negativa; do contrário, a dialética seria indiferente ao que foi posto no início" (ADORNO, 1973, p. 254). Para Adorno, a negação da negação, que não anula a primeira negação, deve necessariamente produzir uma contradição objetiva ao invés de uma afirmação. Ela nos leva a um pensamento do objeto da experiência fundado: "não no princípio, mas na resistência (Widerstand) do outro à identidade" (ADORNO, 1973, p. 162 $)^{14}$. Através da negação da negação retornamos ao objeto que foi posto no início, mas a essência do objeto aparece como resistência à significação produzida pelos esquemas de identificação próprios à estrutura oposicional do pensamento.

Notemos que não se trata aqui de fazer da: "indissolubilidade (Unauflöslichkeit) do objeto um tabu para o sujeito" (ADORNO, 1973, p. 157), via segura seja para o ceticismo seja para um retorno à positividade. Tratase, sobretudo, de reconhecer a existência de uma negação que vem da resistência do objeto enquanto pólo de experiência sensível. Um pouco como Hegel, que mostrava como o fundamento da negação dialética é a negação que vem do fracasso da designação devido ao evanescimento da referência. Mas para não hipostasiar a negação em um bloqueio cético do não-saber, tal resistência do objeto, base para o primado do objeto, só 
pode ser posta como resistência. Posição que já é uma promessa de reconciliação. Isto leva Adorno a jogar a dialética do universal e do particular contra seus próprios limites.

Devemos fazer, dirá Adorno, uma: "crítica recíproca do universal e do particular” (ADORNO, 1973, p. 145). Primeiramente, a crítica do particular. A abstração própria ao universal, que submete seres singulares e capacidades não-idênticas (nichtidentische Einselwesen und Leistungen) a um princípio geral e estrutural de organização, deve ser posta a fim de quebrar a ilusão da imanência. Esta é a primeira negação, que vai da palavra às coisas. Hegel não dizia algo diferente em suas considerações sobre a potência disruptiva do signo.

Mas a auto-reflexão do pensar reconhece que a verdade que é alvo do pensamento consiste em ouvir as aspirações do que foi perdido e em saber retornar ao objeto. Neste retorno, ele encontra o objeto não como positividade designada, mas como ponto de excesso de uma operação de nomeação. De onde se segue a importância da contradição objetiva enquanto momento de exposição deste ponto de excesso no interior de um objeto que foi estruturado por procedimentos de universalização próprios ao pensamento conceitual. Assim: "o não-idêntico constituiria a identidade própria da coisa (Sache) em face de suas identificações" (ADORNO, 1973, p. 159). Trata-se do momento de negação que vai das coisas à palavra.

É possível que este esquema permaneça fundamentalmente hegeliano, sobretudo lá onde ele crê distanciar-se de Hegel. Pois, desde Hegel, a dialética funda-se no reconhecimento da negação ontológica, negação em si que aparece como modo de presença do objeto.

Retornemos, por exemplo, a certos exemplos que Hegel nos fornece no momento de explicar como algo poderia conter em si a contradição. Notemos a importância da afirmação de Hegel a respeito da presença imediata da contradição nas determinações de relação: "Pai é outro do filho e filho é outro do pai, cada termo é apenas como outro do outro (...). [No entanto] O pai, para além da relação ao filho também é algo para si (etwas für sich); mas assim ele não é pai, mas homem em geral (Mann überhaupt)". Hegel se serve do mesmo raciocínio em outro exemplo que toca de maneira direta o problema da designação e lembra os exemplos presentes na discussão hegeliana sobre a certeza sensível: "Alto é o que não 
é baixo, alto é determinado apenas a não ser baixo, e só é na medida em que há baixo; e inversamente, em uma determinação encontra-se seu contrário". Mas: "alto e baixo, direita e esquerda, também são termos refletidos em si, algo fora da relação; mas apenas lugares em geral" (HEGEL, 1986b, p. 77; itálico meu).

Os dois exemplos convergem em uma intuição maior: as determinidades são, ao mesmo tempo, algo em uma oposição real e algo para si, fora do sistema reflexivo de determinações opositivas. Elas têm um modo particular de subsistir próprio irredutível. Hegel já tinha sublinhado este ponto ao comentar a oposição entre o positivo e o negativo enquanto determinações-de-reflexão autônomas: "o negativo também tem, sem relação ao positivo, um subsistir próprio (eigenes Bestehen)" (HEGEL, 1986b, p. 71; itálico meu). Ou seja, o negativo não é simples privação de determinação ou um positivo em si que aparece como negativo apenas no interior de uma relação. Ele é também um negativo em si, fora de sua oposição ao positivo, e esta é a base da operação de restituição da dimensão ontológica do negativo.

Tais frases são muito importantes para a compreensão do verdadeiro caráter da contradição hegeliana. A identidade sempre é enunciada com seu contrário não porque, por exemplo, o pai é o contrário do filho e sempre que pomos o pai deveríamos pressupor o filho. A contradição encontra-se no fato de que o pai é, ao mesmo tempo, determinação para os outros (enquanto significante 'pai' que se determina através de oposições entre outros significantes: 'mãe', 'filho', 'tio') e indeterminação para si (enquanto ele pode sempre se identificar com a negatividade da indeterminação do homem em geral). Como nos indicou Zizek: "não sou apenas 'pai', esta determinação particular, mas para além de seus mandatos simbólicos, não sou nada mais do que o vazio que deles escapam (e que como tal é um produto retroativo)" (ZIZEK, 1999, p. 136). Como se a inscrição da individualidade em um sistema estrutural de oposições produzisse sempre uma espécie de resto, de fracasso reiterado da inscrição que Hegel teria reconhecido através desta maneira de conceber a contradição.

Pode parecer estranho que termos como 'homem em geral' e 'lugar em geral' sejam vistos como pontos de excesso da tentativa de inscrever a individualidade em um sistema estrutural. Pode parecer, por exemplo, que Hegel queira simplesmente mostrar como os sujeitos são, ao mesmo 
tempo, singulares individualizados em um universo estrutural de identidades e diferenças (pai de..., filho de...), e pessoa em geral que tem em comum com outras pessoas propriedades essenciais. No entanto, se assim fosse, não haveria sentido algum em falar de "contradição" neste caso. Se Hegel vê aqui um exemplo privilegiado de contradição é porque "homem em geral" é um lugar vazio que aparece como excesso às determinações relacionais e nos envia à dialética do fundamento (Grund), que se segue às reflexões de Hegel sobre a contradição. Assim, servindo-se de um Witz famoso do idealismo alemão, Hegel dirá: "Estas determinaçõesde-reflexão se superam e a determinação que vai ao abismo (zugrunde gegangene Bestimmung) é a verdadeira determinação da essência” (HEGEL, 1986b, p. 80). Ou ainda: "A essência, enquanto se determina como fundamento, determina-se como o não-determinado, e é apenas o superar de seu ser-determinado que é seu determinar" (HEGEL, 1986b, pp. 80-81). Ou seja, isto nos permite deduzir que "homem em geral" apenas indica o que não se determina através de predicações e individualizações, mas permanece indeterminado e negativo.

De qualquer forma, creio que podemos assim compreender a natureza objetiva da contradição hegeliana. Para Hegel, a contradição é interna ao objeto porque ela exprime a cisão que resulta da operação de inscrição do objeto visado em uma rede de determinações simbólicas ${ }^{15}$. Só assim, a linguagem especulativa pode se reconciliar com a efetividade.

Podemos criticar esta estratégia hegeliana afirmando que ela reduz o que está fora do sistema a um ponto vazio, a uma presença pura desprovida de individualidade predicável. Neste sentido, não seria um acaso o fato de Hegel comparar o horror habitual do pensamento representativo diante da contradição ao horror da "natureza diante do vácuo" (HEGEL, 1986b, p. 78).

Mas tal estratégia pode ser explicada se aceitarmos que, do ponto de vista do conceito, o sensível e o contingente aparecem necessariamente como pura opacidade que resiste a toda determinidade. O que é contingente no objeto da experiência só se manifesta no interior do saber como o que é vazio de conceito. Se Hegel foi capaz de fazer um jogo de palavras para afirmar que contingente (zufällig) é o que deve cair (zu fallen), é porque o contingente é o que cai do conceito, uma queda no vazio do que não é conceito. 
No entanto, o problema hegeliano consiste em saber como apresentar o que é vazio de conceito em uma determinidade conceitual, e não como anular o não-conceitual através do império total do conceito. É possível conservar o não-conceitual sem entrar em sua hipóstase? Eis uma problemática hegeliana por excelência. Como bem sublinhou Mabille (1999), há, no interior mesmo da ontologia hegeliana, um risco de indeterminação que sempre devemos inicialmente assumir para poder após conjurar.

Parece-me que, para Hegel, esta tarefa filosófica maior só pode ser realizada quando tentamos responder à questão das condições dos modos de "apreensão e enunciação (Auffassen und Aussprechen) da contradição". $\mathrm{Ou}$ seja, de uma enunciação que possa apresentar a contradição, que possa levar a contradição à dimensão das operações próprias do conceito. Neste sentido, o conceito é dependente de operações de enunciações contraditórias. Conhecemos algumas destas formas de enunciação e a crítica virulenta de Hegel contra elas. Pensamos, por exemplo, nas considerações hegelianas sobre a ironia enquanto modo de enunciação que internaliza o que nega, o que se oferece na dimensão do enunciado. Tais considerações apenas nos indicam o complemento de um estudo desta natureza: mostrar, através de um estudo comparativo, a peculiaridade do conceito hegeliano em relação a outros modos de formalização da contradição.

\footnotetext{
${ }^{1}$ Isto leva Saussure a se perguntar:"'O que é finalmente uma entidade gramatical? Procedemos exatamente como um geômetra que gostaria de demonstrar as propriedades do círculo e da elipse sem ter dito o que ele chama de círculo e elipse?” (SAUSSURE, 2001, p. 51).

2 Devemos insistir aqui que isto só é possível a partir do projeto hegeliano de não assumir a separação estrita de poderes entre o uso transcendental do entendimento (relação de conceitos, identidade, não-contradição, terceiro excluído) e a relação entre os objetos empíricos (diversidade, oposição ou conflito real). Aos olhos de Hegel, tal divisão só é aceitável a partir do momento em que aceitamos a heterogeneidade radical entre a sensibilidade e o entendimento. Para Hegel, a sensibilidade nunca é determinação de um simples dado: sua diversidade é sempre diversidade da reflexão.

3 Por "princípio de expressibilidade" entende-se que: "para qualquer sentido X e qualquer falante S, não importa o que S queira dizer (intenções a expor, desejos, comunicação em uma sentença, etc.) com X, é possível haver alguma expressão E, de maneira que E seja a exata expressão ou formulação de $\mathrm{X}$. Simbolicamente: $(\mathrm{S})(\mathrm{X})(\mathrm{S}$ significa $\mathrm{X} \rightarrow \mathrm{P}(\exists \mathrm{E})$ (E é a expressão exata de X))" (SEARLE, 1969, p. 20).
} 
${ }^{4}$ É para sublinhar este caráter do ato de fala que Hegel vê a unidade operacional da linguagem no julgamento (desenvolvido como silogismo), e não na proposição, ou mesmo na palavra.

5"Hegel sabe que dizemos sempre mais ou dizemos menos, em suma, sempre algo de outro em relação ao que se queria dizer: é esta discordância que aparece como motor do movimento dialético, é ela que subverte toda proposição” (ZIZEK, 1991, p. 19).

${ }^{6}$ Ver, por exemplo, ARANTES, 1996 e LYOTARD, 1985.Vale a pena lembrar que esta aproximação exige uma explicação. Sabemos que os embrayeurs não são exatamente universais, mas significantes vazios cujo significado só pode ser produzido de maneira pontual no ato de enunciação. No entanto, os universais aos quais Hegel se refere são, neste instante, apenas o que subsiste como abstração de determinidade. Se levarmos isto em conta, a aproximação ganha uma certa validade.

7 Neste sentido, Hegel pode admitir a afirmação de Frege: "não nos contentamos com o sentido, supomos uma denotação" (FREGE, 1971, p. 107). Mas nos parece que ele não pode aceitar que: "com o signo, exprimimos o sentido do nome e designamos a denotação" (idem, p. 107).É exatamente a impossibilidade de convergir sentido e designação no signo que anima a dialética. Para Hegel, o objeto desvanece quando é designado pelo signo. Ele só poderá ser recuperado como negação.

8 Digamos, com Bourgeois, que o especulativo: "enraíza-se na visada - 'indicativa', infradiscursiva - do isto sensível, para ser, em todo seu discurso, a explicação dos requisitos da afirmação original, ‘é', 'há’” (BOUR GEOIS, 1992, p. 89).

${ }^{9}$ Este primado da relação na determinação da identidade dos objetos já pode ser encontrado em textos de juventude de Hegel. Basta lembrarmos aqui desta afirmação presente em $A$ relação entre ceticismo e filosofia, na qual a perspectiva racional é definida como sendo aquela que apreende "relações necessárias a um Outro, (...) pois o racional (Vernünftige) é a própria relação" (HEGEL, 2000b, p. 245)

10 Devemos passar aqui ao problema da referência porque a negação determinada não é apenas o modo de relação entre dois termos, mas fundamentalmente o modo de relação entre conceito e objeto. Neste sentido, lembremos da idéia central de Hegel: o conhecimento das relações não é o resultado de deduções, mas é a formalização de processos da experiência. Conhecer relações não consiste em deduzir, mas em compreender processos. A negação determinada diz respeito fundamentalmente aos modos de efetivação do conceito na experiência. Isto indica que, ao tentar indexar o conceito a um objeto, ao tentar realizar o conceito na experiência, a consciência verá o conceito passar no seu oposto e engendrar um outro objeto (daí porque a negação determinada é o locus da passagem de uma figura da consciência à outra). Neste sentido, a consciência nunca consegue aplicar seu conceito ao caso sem engendrar uma situação que contradiga as aspirações iniciais de significação do conceito. A experiência é exatamente o campo destas inversões (Verkehrung). Lembremos: Hegel está interessado em compreender como o sentido dos conceitos modifica-se a partir do momento em que eles procuram se realizar na experiência. Internalizar o sentido da experiência significa, para Hegel, estruturar relações conceituais através das inversões que a efetividade impõe ao conceito. De uma certa forma, não é o conceito que molda a experiência, mas a experiência que molda o conceito ao impor uma reordenação nas possibilidades de aplicação do conceito. 
${ }^{11}$ Ela nos impede de colocar a questão:" como os objetos são redefinidos, reconstituídos pelo fato de se inscreverem em relações? Quais transformações a noção de objeto recebe pelo fato de assim ser reconstituída pelo pensamento?” (LONGUENESSE, 1981, p. 80).

12 Como vemos na afirmação: "Quando enunciamos o não-ser, não enunciamos algo contrário ao ser, mas apenas algo de outro" (PLATÃO, Sofista, 257b).

13 Neste sentido, Dubarle notou claramente que o termo que teria valor de termo nulo está ausente da doutrina hegeliana do Conceito (DUBARLE et DOZ, 1972, pp. 134-145). Isto acontece porque, em Hegel, o termo negado nunca alcança o valor zero, já que esta função do zero será criticada por Hegel como sendo um "nada abstrato" (abstrakte Nichts). Neste sentido, o interesse hegeliano pelo cálculo infinitesimal estaria ligado à maneira como Hegel estrutura sua compreensão da negação como um impulso ao limite da determinidade. A negação hegeliana nunca alcança o valor zero porque ela leva o nada ao limite do surgir (Entstehen) e o ser ao limite do desaparecer (Vergehen). Na verdade, ela é a exposição deste movimento no qual o ser está desaparecendo e onde o nada está se manifestando em uma determinidade. Movimento cuja exposição exige uma outra compreensão do que é um objeto (para além da idéia do objeto como pólo fixo de identidade). De onde segue também a importância dada por Hegel à noção de grandeza evanescente na compreensão da dinâmica da dialética do devir (Werden). Como dirá Hegel:"Estas grandezas foram determinadas como grandezas que são em seu desaparecer (die in ihrem Verschwinden sind), não antes de seu desaparecer, pois então elas seriam grandezas finitas - nem após seu desaparecer, pois então elas seriam nada” (HEGEL, 1986a, pp. 10-11). Para uma análise detalhada do papel dos infinitesimais na Lógica de Hegel ver FAUSTO, 1996, pp. 23-25.

14 A primeira exposição desta resistência do objeto segue a dialética hegeliana da identidade e da diversidade enquanto recurso a um momento de empirismo na dialética. Assim, Adorno dirá: "o momento da não-identidade no julgamento identificador (identifizierenden Urteil) é facilmente discernível na medida em que todo objeto singular subsumido a uma classe possui determinações que não estão compreendidas na definição de sua classe" (ADORNO, 1973, p. 153). Que um pensamento dialético deva recorrer a um argumento empírico trivial serve de índice para mostrar a necessidade de levar em conta o momento da experiência sensível.

15 É neste sentido que compreendemos a afirmação de Longuenesse: "o que resta, segundo Hegel, uma descoberta inestimável, é a tensão entre a unidade do Eu penso e a multiplicidade do não pensado, ou não completamente unificado pelo pensamento. Todo objeto (pensado) porta em si tal tensão, é por isto que todo objeto porta em si a contradição" (LONGUENESSE, 1981, p. 51). Uma contradição: "entre sua inscrição em uma unidade racional e sua irredutibilidade à unidade" (ibidem, p.52)

\section{Referências bibliográficas}

ADORNO, T. 2001. Dialectique négative. Paris: Payot.

\section{Drei Studien zu Hegel. In: Gesammelte Schriften V,}

Digitale Bibliothek Band 97. 
1973. Negative Dialektik. Frankfurt: Suhrkamp.

ARANTES, P. 1996. Ressentimento da dialética. São Paulo: Paz e Terra.

BENVENISTE, É. 1966. Problèmes de linguistique générale. Paris: Gallimard.

BOURGEOIS, B. 1992. La spéculation hégélienne. In: Études hégéliennes. Paris: PUF.

BRANDOM, R. 2002. Tales of the Mighty Dead: Historical Essays in the Metaphysics of Intentionality. Harvard University Press.

DAVID-MÉNARD, M. 1990. La folie dans la raison pure: Kant lecteur de Swedenborg. Paris: Vrin.

DELEUZE, G. 2000. Différence et répétition. Paris: PUF.

DERRIDA, J. 1991. Margens da filosofia. Campinas: Papirus.

DUBARLE et DOZ. 1972. Logique et dialectique. Paris: Larousse.

FAUSTO, R. 1996. Sur le concept de capital: idée d'une logique dialectique. Paris: L'Harmattan.

FREGE, G. 1971. Écrits logiques et philosophiques. Paris: Seuil.

GIMMLER, A. 2004. Pragmatic aspects of Hegel's thought. In:

EGGINTON, W. The Pragmatic Turn in Philosophy. New York: SUNY.

HEGEL, G. W. F. 2000. Enzyklopädie der philosophischen Wissenschaften. In: Hegel Werke, CDR, Berlin: Talpa. . 2000b. Verhältnis des Skeptizismus zur Philosophie. In: Hegel Werke, CDR, Berlin: Talpa. 1986a. Wissenshaft der Logik I. Frankfurt: Suhrkamp. 1986b. Wissenschaft der Logik II. Frankfurt: Suhrkamp. 1988. Phänomenologie des Geistes. Hamburgo: Felix Meiner. 1992a. Fenomenologia do Espírito. Vol. I, Petrópolis:Vozes. 1992b. Fenomenologia do Espírito.Vol. II, Petrópolis:Vozes. 
.2000c. Vorlesungen über die Philosophie der Religion. In: Hegel Werke, CDR, Berlin: Talpa.

1982. Science de la logique. Tome I: La logique objective. Livre II:

La doctrine de l'essence. Paris: Aubier.

1988. Encyclopédie des sciences philosophiques. Tome III:

Philosophie de l'Esprit, Paris:Vrin.

HENRICH, D. 1967, Hegel im Kontext. Frankfurt: Suhrkamp.

KANT, I. 2005. Ensaio para introduzir em filosofia o conceito de grandeza negativa. In: Escritos pré-críticos, São Paulo: Unesp.

LEBRUN, G. 2002. Kant e o fim da metafísica. São Paulo: Martins Fontes. 1971. La patience du concept. Paris: Gallimard.

LONGUENESSE, B. 1981. Hegel et la critique de la métaphysique. Paris:Vrin.

LYOTARD, J-F. 1986. Discours, figure. Paris: Klincksieck.

MABILLE, B. 1999. Hegel: l'épreuve de la contingence. Paris: Aubier.

MILNER, J-C. 1978. L'amour de la langue. Paris: Seuil.

PINKARD, T. 1994. Hegel's Phenomenology: the Sociability of Reason.

Cambridge University Press.

QUINE, W. 1980. A relatividade ontológica. São Paulo: Abril Cultural (col. Os Pensadores).

RORTY, R. 1988. A filosofia e o espelho da natureza. Lisboa: Dom Quixote.

SAUSSURE, F. 1972. Cours de linguistique générale. Édition critique par Tullio de Mauro, Paris: Payot.

2002. Écrits de linguistique générale. Paris: Gallimard.

SEARLE, J. 1969. Speech Acts. Cambridge University Press.

ZIZEK, S. 1991. O mais sublime dos histéricos: Hegel com Lacan. Rio de Janeiro: Jorge Zahar.

1999. Subversions du sujet. Rennes: P.U.R. 